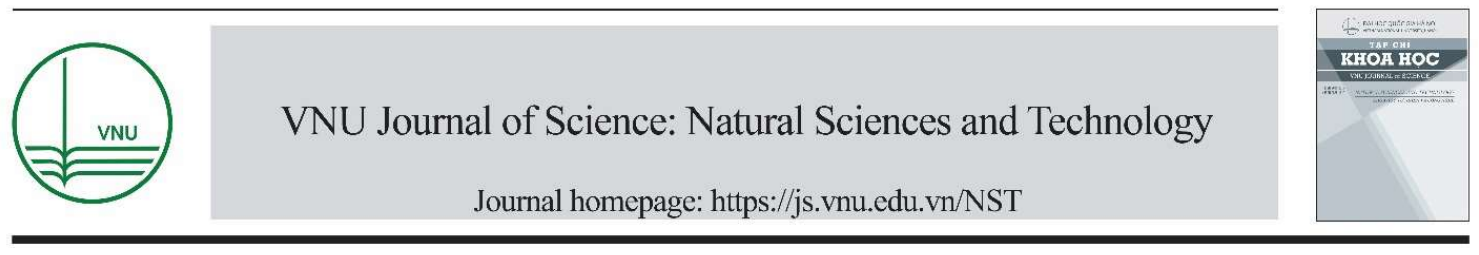

Original Article

\title{
Diversity of Medicinal Plants Resources to be Useb by the Kho Mu Community in Special Use Forest, Sop Cop District, Son La Province
}

\author{
Vu Thi Lien*, Song A Đau, Leo Van Nghia \\ Tay Bac University, Quyet Tam Ward, Son La City, Son La province, Vietnam \\ Received 26 August 2020 \\ Revised 25 May 2021; Accepted 24 June 2021
}

\begin{abstract}
This research was conducted to assess the diversity of medicinal plant resources in special use forest, Sop Cop district, Son La province.By traditional botanical research method that we carried out since July 2019 to March 2020.The results showed that, there were 389 species of medicinal plants belonging to 294 genera and 109 families of 4 divisions of vascular plant. There were 10 families with the high number of species. The medicinal plants were used differently by the Kho $\mathrm{Mu}$ ethnic to treat 18 groups of diseases, of which the plants were used to treat gastrointestinal diseases had the highest percentage of species, 102 species $(26,22 \%)$. In the parts used as medicine, leaves are most used accounting for from $26,74 \%$. The whole trees and roots were used also quite large, including whole tree with 77 species, roots with 66 species. There were 28 medicinal species (accounting for 7,19\%) that had been identified in the Vietnam's Red Data Book (2007), have 18 species listed in the Vietnam's Red List of Medicinal Plants, that wrote by Nguyen Tap (2019) and 12 species listed in the Governmental Decree 06/2019/NĐ-CP. These species had limited individuals that need to have policies for conservation and development.
\end{abstract}

Keywords: Diversity of Medicinal Plants, Kho Mu Ethnic Minority, Protection, Sop Cop SpecialUse Forest.

\footnotetext{
${ }^{\star}$ Corresponding Authors.

Email Address: luocvang2018@utb.edu.vn

https://doi.org/10. 25073/2588-1140/vnunst.5119
} 


\title{
Đa dạng nguồn tài nguyên cây thuốc được cộng đồng dân tộc Khơ Mú sử dụng tại rừng đặc dụng, phòng hộ Sốp Cộp, tỉnh Sơn La
}

\author{
Vũ Thị Liên, Lèo Văn Nghĩa, Sộng A Đậu \\ Trường Đại học Tây Bắc, phường Quyết Tâm, TP. Sơn La, tỉnh Sơn La \\ Nhận ngày 26 tháng 8 năm 2020 \\ Chỉn sủa ngày 25 tháng 5 năm 2021; Chấp nhận đăng ngày 24 tháng 6 năm 2021
}

\begin{abstract}
Tóm tắt: Nghiên cứu này được thực hiện nhằm đánh giá đa dạng nguồn tài nguyên cây thuốc được cộng đồng dân tộc Khơ Mú sử dụng tại rừng Đặc dụng, Phòng hộ Sốp Cộp, tỉnh Sơn La. Bằng phương pháp nghiên cứu thực vật học truyền thống được thực hiện từ tháng 7/2019 đến tháng 3/2020. Kết quả thu được 389 loài cây thuốc thuộc 294 chi, 109 họ thuộc 4 ngành thực vật bậc cao có mạch. Có 10 họ có nhiều loài nhất. Các loài cây thuốc được dân tộc Khơ Mú sử dụng khác nhau để điều trị 18 nhóm bệnh, trong đó cây thuốc chữa bệnh về đường tiểu hoá chiếm tỷ lệ cao nhất về số loài là 102 loài $(26,22 \%)$. Trong các bộ phận được sử dụng làm thuốc lá được sử dụng nhiều nhất chiếm $26,74 \%$. Nơi phân bố cây thuốc ở các dạng sinh cảnh nhu: ở rừng, nương rẫy, ven đường, vườn nhà, thảm cây bụi, khe nước ẩm. Đã xác định được 28 loài thuốc (chiếm 7,19\%) có nguy cơ bị đe dọa được ghi trong Sách đỏ Việt Nam (2007), có 18 loài được ghi trong Danh lục Đỏ cây thuốc Việt Nam, 2019 của Nguyễn Tập và 12 loài trong Nghị định 06/2019/NĐ-CP. Đây là những loài có số cá thể còn ít nên cần có những chính sách ưu tiên bảo tồn và phát triển.
\end{abstract}

Tù khóa: Đa dạng cây thuốc, dân tộc Khơ Mú, Phòng hộ, rừng Đặc dụng Sốp Cộp

\section{Mở đầu}

Rừng Đặc dụng, Phòng hộ Sốp Cộp tỉnh Sơn La nằm trong địa giới hành chính của 6 xã thuộc 2 huyện Sốp Cộp (xã Sốp Cộp, Dồm Cang, Púng Bánh) và Sông Mã (Nậm Mằn, Huổi Một, Mường Cai) tỉnh Sơn La. Trên địa bàn có 30.301 người gồm 8 dân tộc sinh sống, trong đó dân tộc Thái có số lượng đông nhất chiếm $62,66 \%$, dân tộc Mông chiếm 25,21\%, dân tộc Khơ Mú chiếm 3,99\%, dân tộc Sinh Mun chiếm 3,36\%, dân tộc Kinh chiếm 3,04\%, dân tộc La Ha chiếm 1,48\%,

\footnotetext{
*Tác giả liên hệ.

Địa chi email: luocvang2018@utb.edu.vn
}

https://doi.org/10. 25073/2588-1140/vnunst.5119 dân tộc Lào chiếm $0,17 \%$ và dân tộc Mường chiếm $0,09 \%$ [1]. Chính sự khá đa dạng về dân tộc cùng với sự khác biệt về phong tục tập quán, văn hóa trong từng cộng đồng dân tộc đã tạo nên sự đa dạng và phong phú trong kinh nghiệm sử dụng thực vật xung quanh làm thuốc chữa bệnh.Từ lâu đời cộng đồng dân tộc Khơ Mú ở rừng Đặc dụng, Phòng hộ Sốp Cộp cũng có nhiều kinh nghiệm chữa bệnh độc đáo và phong phú bằng sử dụng cây cỏ làm thuốc trong hoạt động chăm sóc sức khỏe cộng đồng. Đây chính là 
nguồn tri thức bản địa vô cùng quý báu cần khai thác, bảo tồn và phát triển. Vì vậy, đã có rất nhiều công trình nghiên cứu ở trên thế giới và Việt Nam về cây thuốc cũng như kinh nghiệm dân gian đã được thực hiện và mang lại giá trị khoa học và thực tiễn [2-9]. Tuy nhiên, hiện nay do nhiều nguyên nhân khác nhau như: do phát nương làm rẫy, chăn thả gia súc, tình trạng khai thác và mua bán các sản phẩm từ rừng diễn ra một cách phức tạp,... dẫn đến làm cho diện tích rừng ngày càng bị thu hẹp và sự suy giảm nguồn tài nguyên cây thuốc là không thể tránh khỏi. Đặc biệt với những loài có khả năng tái sinh và sinh trưởng chậm thì nguy cơ bị đe dọa và tuyệt chủng là rất cao. Thực tế cho thấy tính độc đáo trong việc sử dụng cây thuốc thể hiện ở kinh nghiệm của từng cá nhân hay của mỗi cộng đồng dân tộc đặc biệt là dân tộc Khơ Mú ở khu vực nghiên cứu đã đang sở hữu một kho tri thức bản địa về các bài thuốc nam, trải qua thời gian, các bài thuốc có tính độc đáo và trở nên thông dụng. Song, trong số hàng trăm, hàng nghìn bài thuốc được lưu truyền lại qua nhiều thế hệ chủ yếu bằng cách truyền miệng, nên những kinh nghiệm quý báu đó đang dần bị mai một khi lớp người già mất đi, họ mang theo cả những kiến thức về cây thuốc và những bài thuốc hay. Thế hệ trẻ ít người tiếp thu những kiến thức mang tính bản địa đã khiến cho những cây thuốc quý, bài thuốc hay bị quên lãng.

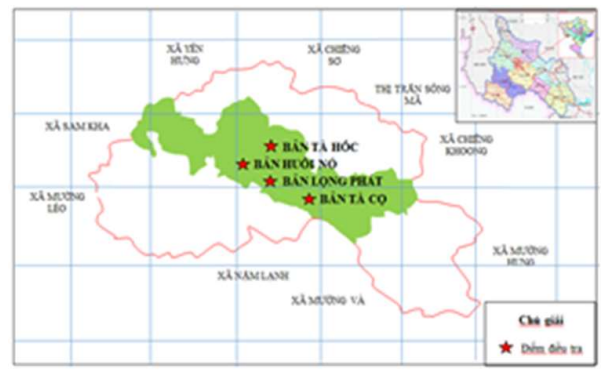

Hình 1. Vị trí điều tra tại khu vực nghiên cứu.

Nhằm góp phần bảo tồn đa dạng sinh học sưu tầm và lưu giữ các tri thức bản địa truyền thống trong việc gữi gìn và phát triển nguồn tài nguyên cây thuốc được mệnh danh là "vàng xanh" ở rừng Đặc dụng, Phòng hộ Sốp Cộp là việc làm rất cần thiết. Đã có một số công trình nghiên cứu về thực vật ở đây như nghiên cứu tài nguyên cây thuốc tác giả Trần Thị Thu Huyền [10], cây có tinh dầu của Vũ Thị Liên và cs [11]...

\section{Phương pháp nghiên cứu}

\section{1. Đối tượng, phạm vi nghiên cưu}

Các loài thực vật và kinh nghiệm sử dụng thực vật làm thuốc của dân tộc Khơ Mú tại rừng Đặc dụng Sốp Cộp, tỉnh Sơn La

- Thời gian thực hiện từ tháng 7 năm 2019 đến tháng 3 năm 2020

- Địa điểm nghiên cứu: Tại bản Tà Hốc xã Huổi Một, bản Tà Cọ xã Sốp Cộp, bản Huổi Nó và Lọng Phát xã Dổm Cang, thuộc rừng Đặc dụng, Phòng hộ Sốp Cộp, tỉnh Sơn La

\subsection{Phương pháp nghiên cứu}

- Phương pháp kế thừa tài liệu: Kế thừa những kinh nghiệm sử dụng cây thuốc của các ông lang, bà mế dân tộc Khơ Mú và các công trình nghiên cứu khoa học trước đây về cây thuốc, các tài liệu nghiên cứu có liên quan đến đề tài, có chọn lọc.

- Phương pháp đánh giá tính đa dạng nguồn tài nguyên cây thuốc: Dựa trên phương pháp của Nguyễn Nghĩa Thìn trong các phương pháp nghiên cứu thực vật [12]:

+ Điều tra theo tuyến: Lập tuyến điều tra dựa vào bản đồ của khu vực và kết quả điều tra sơ bộ, tiến hành lập 8 tuyến điều tra. Trên mỗi tuyến thu thập, ghi lại đặc điểm hình thái, thống kê các loài cây thuốc, chụp ảnh mẫu, sử dụng GPS để xác định tọa độ địa lý, độ cao phân bố cây thuốc... Việc điều tra tại các tuyến có đi cùng người dân bản địa thường xuyên thu hái cây thuốc và thầy thuốc địa phương.

+ Các tuyến điều tra: Gồm 8 tuyến với tổng chiều dài tuyến điều tra là $57 \mathrm{~km}$ (Bảng 1 ). Các tuyến này phân bố trên các đai cao, các dạng sinh cảnh và kiểu trạng thái thảm thực vật rừng khác nhau (quanh bản, ven suối, rừng tái sinh, rừng ẩm thường xanh trên núi đất, núi đá vôi, thảm cỏ,...) của khu vực nghiên cứu. Ngoài ra còn 
điều tra bổ sung tại vườn nhà người dân và thu mẫu tiêu bản tại thực địa.

Bảng 1. Vị trí các tuyến điều tra.

\begin{tabular}{|c|c|c|c|c|c|c|}
\hline \multirow{2}{*}{ STT } & \multirow{2}{*}{ Tuyến điều tra } & \multicolumn{2}{|c|}{ Điểm đầu } & \multicolumn{2}{|c|}{ Điểm cuối } & \multirow{2}{*}{ Chiều dài (m) } \\
\hline & & Kinh độ & Vĩ độ & Kinh độ & Vĩ độ & \\
\hline 1 & Tuyến KMA & $103^{\circ} 39^{\prime} 38^{\prime \prime}$ & 2101'19"' & $103^{\circ} 39^{\prime} 47^{\prime \prime}$ & $21^{\circ} 01^{\prime} 49^{\prime \prime}$ & 9.000 \\
\hline 2 & Tuyến KMB & $103^{\circ} 37^{\prime} 19^{\prime \prime}$ & $21^{\circ} 01^{\prime} 19^{\prime \prime}$ & $104^{\circ} 22^{\prime} 49^{\prime \prime}$ & $20^{\circ} 90^{\prime} 56^{\prime \prime}$ & 7.000 \\
\hline 3 & $\overline{\mathrm{MC}}$ & $103^{\circ} 37^{\prime} 26^{\prime \prime}$ & $20^{\circ} 57^{\prime} 55^{\prime \prime}$ & $103^{\circ} 37^{\prime} 11^{\prime \prime}$ & $20^{\circ} 57^{\prime} 52^{\prime \prime}$ & 7.000 \\
\hline 4 & Tuyến KMD & $103^{\circ} 37^{\prime} 25^{\prime \prime}$ & $20^{\circ} 57^{\prime} 56^{\prime \prime}$ & $103^{\circ} 37^{\prime} 69^{\prime \prime}$ & $20^{\circ} 57^{\prime} 99^{\prime \prime}$ & 8.000 \\
\hline 5 & Tuyến KME & $103^{\circ} 35^{\prime} 39^{\prime \prime}$ & $20^{\circ} 57^{\prime} 66^{\prime \prime}$ & $103^{\circ} 35^{\prime} 39^{\prime \prime}$ & $20^{\circ} 58^{\prime} 05^{\prime \prime}$ & 6,500 \\
\hline 6 & Tuyến KMF & $103^{\circ} 35^{\prime} 39^{\prime \prime}$ & $20^{\circ} 57^{\prime} 66^{\prime \prime}$ & $103^{\circ} 35^{\prime} 83^{\prime \prime}$ & $20^{\circ} 57^{\prime} 25^{\prime \prime}$ & 6.000 \\
\hline 7 & Tuyến KMG & $103^{\circ} 37^{\prime} 35^{\prime \prime}$ & $20^{\circ} 57^{\prime} 29^{\prime \prime}$ & $103^{\circ} 36^{\prime} 35^{\prime \prime}$ & $20^{\circ} 57^{\prime} 28^{\prime \prime}$ & 7.000 \\
\hline 8 & Tuyến KMH & $103^{\circ} 35^{\prime} 35^{\prime \prime}$ & $20^{\circ} 57^{\prime} 29^{\prime \prime}$ & $103^{\circ} 365^{\prime} 17^{\prime \prime}$ & $20^{\circ} 57^{\prime} 37^{\prime \prime}$ & 6.500 \\
\hline
\end{tabular}

- Phương pháp phân tích và phân loại mẫu: Xác định tên khoa học các loài thực vật bằng phương pháp hình thái so sánh theo các tài liệu của các tác giả sau: Cây cỏ Việt Nam của Phạm Hoàng Hộ [13], Danh lục các loài Thực vật Việt Nam của Nguyễn Tiến Bân (tập 2-2003, tập 3-2005) [14]; Từ điển cây thuốc của Võ Văn Chi [15]; Những cây thuốc và vị thuốc Việt Nam của Đố Tất Lợi [16]. Xử lý mẫu thu được và xác định tên khoa học của 389 mẫu. Mẫu vật được lưu giữ tại phòng Bảo tàng, Trường Đại học Tây Bắc. Phân nhóm công dụng của các loài thực vật làm thuốc chủ yếu dựa vào kinh nghiệm thực tế của dân tộc Khơ Mú tại khu vực nghiên cứu và tài liệu của Võ Văn Chi (tập 1,2) [15], Đỗ Tất Lợi [16], Trần Đình Lý [17]. Danh lục các loài cây thuốc sắp xếp theo Brummitt [18] .

- Phương pháp điều tra phỏng vấn: Theo các phương pháp nghiên cứu thực vật dân tộc học Gary J. Martin (2002) [19]: Phương pháp RRA (RRA-Rurla RapidAppraisal- Phương pháp đánh giá nhanh nông thôn); Phương pháp PRA (PRA - Participatory Rural Appraisal -Phương pháp đánh giá nông thôn có sự tham gia của người dân) sử dụng kết hợp cả hai phương pháp này để thu thập thông tin. Đối tượng phỏng vấn là các ông lang, bà mế có kinh nghiệm sử dụng các loài cây làm thuốc và các bài thuốc gia truyền, người thu hái, người bán, hộ gia đình là 120 người có độ tuổi từ 25 tuổi đến 89 tuổi, các tiêu chí dựa theo: Phiếu điều tra cây thuốc trong cộng đồng và phiếu điều tra bài thuốc dân gian (Viện Dược liệu, Bộ Y tế).

- Đánh giá mức độ nguy cấp của các loài cây thuốc: Theo các tài liệu Sách đỏ Việt Nam phần II- Thực vật (2007) [20], Danh lục Đỏ cây thuốc Việt Nam [21] và Nghị định 06/2019/NĐ-CP [22]

Thống kê, xử lý và tính toán các số liệu điều tra, phiểu phỏng vấn bằng phần mềm Excell.

\section{Kết quả và thảo luận}

3.1. Đa dạng các bậc taxon của nguồn tài nguyên cây thuốc

\section{a. Đa dạng bậc ngành}

Kết quả điều tra thực vật được sử dụng theo kinh nghiệm của dân tộc Khơ Mú để làm thuốc chữa bệnh tại rừng Đặc dụng, Phòng hộ Sốp Cộp, tỉnh Sơn La đã xác định được 389 loài cây thuốc, 294 chi, 109 họ thuộc 4 ngành: Thông đất (Lycopodiophyta); Dương xỉ (Polypodiophyta), ngành Hạt trần (Pinophyta) và ngành Ngọc lan (Magnoliophyta) (Bảng 2). Kết quả Bảng 2 cho thấy, phần lớn các taxon tập trung trong ngành Ngọc lan (Magnoliophyta) với 365 loài, chiếm $94,09 \%$ tổng số loài, 276 chi, chiếm 93,88\% tổng số chi và 94 họ, chiếm $86,25 \%$ tổng số họ và thấp nhất là ngành Thông (Pinophyta) với 1 loài, 
chiếm $0,26 \%$ tổng số loài, 1 chi, chiếm $0,34 \%$ tổng số chi và 1 họ, chiếm $0,92 \%$ tổng số họ. Như vậy, các taxon chủ yếu tập trung ở ngành Ngọc lan với số chi và loài chiếm trên $90 \%$, điều này hoàn toàn hợp lý so với sự tiến hóa của thực vật bởi vì ngành Ngọc lan là ngành chiếm ưu thế của thực vật bậc cao có mạch. Các chỉ tiêu về cấu trúc hệ thống (Systematic structure) của thực vật làm thuốc được dân tộc Khơ Mú sử dụng: chỉ số đa dạng họ là 2,69 tức là trung bình mỗi họ có gần 3 loài; chỉ số đa dạng chi là 1,32 tức trung bình mỗi chi có 1 loài; số chi trung bình của mỗi họ là 3,57 tức trung bình mỗi họ có gần 4 chi được dân tộc Khơ Mú sử dụng làm thuốc chữa bệnh (Bảng 2)

Sự phân bố không đều nhau của các taxon không chỉ được thể hiện giữa các ngành mà còn được thể hiện giữa các taxon lớp trong ngành Ngọc lan. Theo Phạm Bình Quyền, Nguyễn Nghĩa Thìn [23], tỷ trọng của lớp Hai lá mầm so với lớp Một lá mầm ở vùng nhiệt đới luôn lớn hơn 3. Thực vật làm thuốc được dân tộc Khơ Mú sử dụng ở khu vực nghiên cứu có tỷ trọng lớp Hai lá mầm (Dicotyledones) với số lượng các taxon chiếm ưu thế với $76,59 \%$ tổng số họ, với $80,08 \%$ số chi và $80,82 \%$ số loài của ngành; lớp Một lá mầm (Moncotyledones) với 22 họ (chiếm 23,41\%); 53 chi (chiếm 19,20\%) và 70 loài (chiếm 19,18\%). Tỷ lệ lớp Dicotyledones trên lớp Moncotyledones là: 3,$3 ; 4,2 ; 4,2$ nghĩa là có gần 3 họ của lớp Dicotyledones thì có 1 họ lớp Moncotyledones; có 4 chi Dicotyledones có 1 chi của lớp Moncotyledones; có 4 loài của lớp Dicotyledones thì có 1 loài của lớp Moncotyledones. Qua Bảng 2 thấy rằng thực vật làm thuốc được dân tộc Khơ Mú sử dụng ở rừng Đặc dụng, Phòng hộ Sốp Cộp, tỉnh Sơn La có tỷ trọng của lớp Hai lá mầm so với lớp Một lá mầm luôn cao hơn 3 , thậm chí đạt đến 4,2 . Điều này cho thấy hệ thực vật nơi đây mang tính chất nhiệt đới rất rõ. Kết quả tương tự cũng được chỉ ra trong nghiên cứu về đa dạng cây thuốc thuộc ngành Ngọc Lan (Magnoliophyta) tại khu Bảo tồn thiên nhiên Tà Xùa tỉnh Sơn La của Phạm Quỳnh Anh và cs [2], Trần Thị Thu Huyền [10], Vũ Thị Liên và cs [3], [11].

Bảng 1. Số loài cây thuốc được dân tộc Khơ Mú sử dụng ở khu vực nghiên cứu.

\begin{tabular}{|c|c|c|c|c|c|c|c|}
\hline \multirow[b]{2}{*}{ STT } & \multirow[b]{2}{*}{ Ngành thực vật } & \multicolumn{2}{|c|}{ Họ } & \multicolumn{2}{|c|}{ Chi } & \multicolumn{2}{|c|}{ Loài } \\
\hline & & $\begin{array}{c}\text { Số } \\
\text { lượng }\end{array}$ & $\begin{array}{l}\text { Tỷ lệ } \\
(\%)\end{array}$ & $\begin{array}{c}\text { Số } \\
\text { lượng }\end{array}$ & $\begin{array}{l}\text { Tỷ lệ } \\
(\%)\end{array}$ & $\begin{array}{c}\text { Số } \\
\text { lượng }\end{array}$ & $\begin{array}{l}\text { Tỷ lệ } \\
(\%)\end{array}$ \\
\hline 1 & $\begin{array}{l}\text { Ngành Thông đất } \\
\text { (Lycopodiophyta) }\end{array}$ & 2 & 1,83 & 2 & 0,68 & 2 & 0,51 \\
\hline 2 & $\begin{array}{l}\text { Ngành Dương xỉ } \\
\text { (Polypodiophyta) }\end{array}$ & 12 & 11,0 & 15 & 5,10 & 20 & 5,14 \\
\hline 3 & Ngành Hạt trần (Pinophyta) & 1 & 0,92 & 1 & 0,34 & 1 & 0,26 \\
\hline \multirow[t]{4}{*}{4} & $\begin{array}{l}\text { Ngành Ngọc lan } \\
\text { (Magnoliophyta) }\end{array}$ & 94 & 86,25 & 276 & 93,88 & 365 & 94,09 \\
\hline & $\begin{array}{l}\text { Lớp hai lá mầm } \\
\text { (Dicotyledones)-D }\end{array}$ & 72 & 76,6 & 223 & 80,8 & 295 & 80,82 \\
\hline & $\begin{array}{l}\text { Lớp một lá mầm } \\
\text { (Moncotyledones)-M }\end{array}$ & 22 & 23,40 & 53 & 19,20 & 70 & 19,18 \\
\hline & Tỉ lệ D/M & \multicolumn{2}{|c|}{3,3} & \multicolumn{2}{|c|}{4,2} & \multicolumn{2}{|c|}{4,2} \\
\hline & Tổng & 109 & 100 & 294 & 100 & 389 & 100 \\
\hline
\end{tabular}




\section{b. Đa dạng ở bậc dưới ngành}

Sự đa dạng của hệ thực vật còn được xem xét ở bậc dưới ngành, cụ thể là cấp độ họ, chi và loài. Ở mỗi nơi, các taxon có số loài phổ biến nhất được xem là những taxon đặc trưng cho hệ thực vật địa phương đó. Bằng cách tính số lượng loài và chi trong một họ và số lượng loài trong mỗi chi, đề tài đã tìm ra được các họ có nhiều loài nhất và các chi có nhiều loài nhất để làm cơ sở cho việc đánh giá tính đa dạng của thực vật thể hiện ở các cấp độ taxon dưới ngành. Cụ thể như sau:

\section{* Đa dạng họ}

Trong các họ thực vật được sử dụng tại khu vực nghiên cứu, mức độ sử dụng cũng được tập trung vào một số ít họ nhất định. Đây cũng là các họ có số lượng loài lớn ở Việt Nam và có sự phân bố rộng. Bằng cách tính số lượng loài trong một họ, đề tài đã tìm ra được 10 họ có nhiều loài nhất để làm cơ sở cho việc đánh giá tính đa dạng của thực vật thể hiện ở các cấp độ taxon dưới ngành.

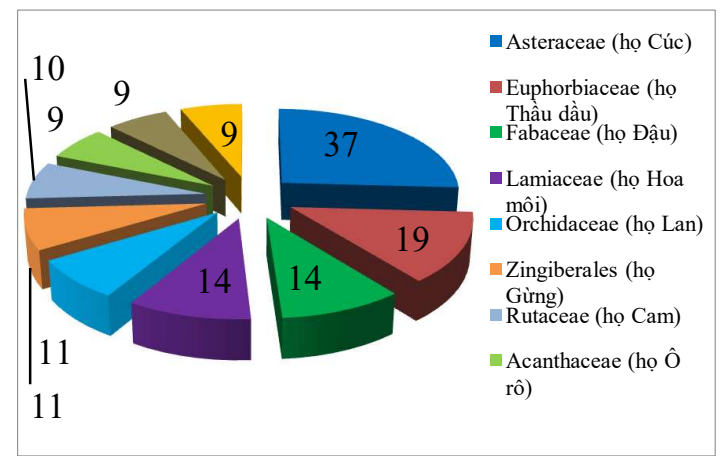

Hình 2. Các họ thực vật được sử dụng nhiều nhất.

Kết quả ở Hình 2 cho thấy trong số 109 họ thực vật làm thuốc theo kinh nghiệm của dân tộc Khơ Mú ở rừng Đặc dụng, Phòng hộ Sốp Cộp, một số họ có nhiều loài cây thuốc như họ Cúc (Asteraceae) có số loài nhiều nhất với 37 loài, chiếm $9,51 \%$ tổng số loài. Tiếp đến là họ Thầu dầu (Euphorbiaceae) với 19 loài, chiếm 4,88\% tổng số loài. Hai họ
Đậu (Fabaceae) và họ Hoa môi (Lamiaceae) có 14 loài, chiếm 3,59\%; Hai họ Lan (Orchidaceae) và họ Gừng (Zingiberales) với 11 loài, chiếm 2,83\%; họ Cam (Rutaceae) có 10 loài, chiếm 2,57\%. Ba họ Ô rô (Acanthaceae), họ Cà phê (Rubiaceae) và họ Ráy (Araceae) có 9 loài, chiếm 2,31\%; Các họ còn lại có ít hơn 9 loài, chiếm $63,28 \%$ tổng số loài. Đây đều là những họ lớn và giàu loài của hệ thực vật Việt Nam.

* Đa dạng chi

Kết quả nghiên cứu đã xác định được 4 chi có số loài đa dạng nhất trong số 294 chi làm thuốc tại khu vực nghiên cứu. Chi Sung (Ficus) và Rau răm (Polygonum) có số loài nhiều nhất với 7 loài, chiếm $1,79 \%$ tổng số thực vật làm thuốc đó là chi đại diện cho rừng nhiệt đới, tiếp theo là chi Cà (Solanum) với 6 loài $(1,54 \%)$ và chi Thầu dầu (Euphorbia) với 4 loài $(1,02 \%)$. Các chi còn lại dưới 4 loài, chiếm 93,86\% tổng số loài. Kết quả cho thấy số lượng các chi có số loài nhiều hơn 4 là rất ít (4 chi). Như vậy có thể kết luận thành phần cây thuốc được cộng đồng Khơ Mú ở khu vực nghiên cứu sử dụng rất đa dạng về bậc chi

* Đa dạng bậc loài

So với số cây thuốc có ở Việt Nam hiện có 4700 loài (theo số liệu của Võ Văn Chi [15]) thì hệ thực vật được dân tộc Khơ Mú sử dụng để chữa bệnh là 389 loài chiếm $8,28 \%$ tổng số loài. Số liệu trên cho thấy kinh nghiệm sử dụng cây cỏ làm thuốc chữa bệnh, chăm sóc sức khỏe cho cộng đồng của dân tộc Khơ Mú tại khu vực nghiên cứu cũng khá phong phú.

\section{2. Đa dạng về bộ phận sử dụng của nguồn tài nguyên cây thuốc}

Nghiên cứu nắm rõ về các bộ phận làm thuốc không chỉ cho thấy tính phong phú và đa dạng 
trong khả năng chữa bệnh của các bộ phận đó, mà còn có ý nghĩa giúp cho biện pháp bảo tồn và phát triển nguồn dược liệu có hiệu quả. Đồng thời, việc nghiên cứu các bộ phận sử dụng làm thuốc còn có giá trị đánh giá được tính bền vững trong thực trạng khai thác và sử dụng tài nguyên cây thuốc của dân tộc Khơ Mú tại khu vực nghiên cứu.

Bảng 3. Đa dạng bộ phận cây được dân tộc Khơ Mú sử dụng làm thuốc.

\begin{tabular}{|c|c|c|c|}
\hline Stt & $\begin{array}{c}\text { Bộ phận sử } \\
\text { dụng }\end{array}$ & $\begin{array}{c}\text { Số lượng } \\
\text { loài }\end{array}$ & $\begin{array}{c}\text { Tỷ lệ } \\
(\%)\end{array}$ \\
\hline 1 & Lá & 104 & 26,74 \\
\hline 2 & Thân & 88 & 22,62 \\
\hline 3 & Cả cây & 77 & 19,79 \\
\hline 4 & Rễ & 66 & 16,97 \\
\hline 5 & Vỏ thân & 28 & 7,19 \\
\hline 6 & Củ & 22 & 5,66 \\
\hline 7 & Hậ & 21 & 5,39 \\
\hline 8 & Quả & 10 & 2,57 \\
\hline 9 & Hoa & 10 & 2,57 \\
\hline 10 & Nhựa & 6 & 1,54 \\
\hline 11 & Vỏ rễ̂ & 4 & 1,03 \\
\hline
\end{tabular}

Trong 389 loài cây thuốc đã được thống kê, mỗi loài cây khác nhau có thể sử dụng một hoặc đồng thời nhiều bộ phận khác nhau để chữa bệnh. Kết quả điều tra về các bộ phận sử dụng làm thuốc theo kinh nghiệm của dân tộc Khơ Mú ở rừng Đặc dụng, Phòng hộ Sốp Cộp thể hiện ở (Bảng 3), cho thấy lá, thân, cả cây, rễ, vỏ thân, củ, hạt là các bộ phận được sử dụng nhiều hơn các thành phần khác như, quả, vỏ rễ, hoa và nhựa. Kết quả Bảng 3 cho thấy lá là bộ phận được sử dụng nhiều nhất và thông dụng nhất với 104 loài, chiếm $26,74 \%$ trong tổng số loài thu được, có thể nói lá cây làm thuốc khá đa dạng cả về cách sử dụng lẫn công dụng, việc sử dụng này thuận tiện trong việc thu hái và có ảnh hưởng ít đến tới sinh trưởng tái sinh của cây thuốc so với việc khai thác các bộ phận khác của cây. Kết quả tương tự cũng được chỉ ra trong nghiên cứu về bộ phận làm thuốc của dân tộc Mông tại xã Mường Phăng, huyện Điện Biên, tỉnh Điện Biên của Vũ Thị Liên và cs [4], hay trong nghiên cứu về bộ phận làm thuốc theo kinh nghiệm của các các dân tộc thiểu số ở tỉnh Thái Nguyên của Lê Thị Thanh Hương, Nguyễn Trung Thành [5]. Một số nghiên cứu được tiến hành ở trên thế giới cũng cho thấy, lá được sử dụng nhiều hơn các phần khác của cây [6-9]. Việc sử dụng lá làm thuốc giúp làm giảm mức độ của mối đe dọa đối với các loài thực vật làm thuốc hay giúp cho việc thu hoạch bền vững cây thuốc; đứng thứ hai là bộ phận thân với 88 loài, chiếm 22,62\%; tiếp đó là sử dụng cả cây với 77 loài, chiếm 19,79\%. Sử dụng rễ் là 66 loài chiếm 16,97\%. Việc sử dụng các bộ phận cả cây và rễ có tỷ lệ khá lớn, điều này sẽ ảnh hưởng không nhỏ tới công tác bảo tồn và phát triển bền vững cây thuốc, vì sẽ dẫn đến việc hủy hoại đời sống của các cây thuốc khi không còn rễ hoặc lấy tất cả các bộ phận của cây thuốc đó làm thuốc. Qua đây cũng thây rằng, cần phải đẩy mạnh công tác gây trồng rộng rãi các loài cây thuốc sử dụng bộ phận rễ và cả cây để chữa bệnh để từ đó giảm thiểu được sự suy giảm số lượng cây thuốc nghiêm trọng khi công tác chữa trị bệnh của dân tộc Khơ Mú phát triển hơn. Đây cũng là một nhiệm vụ trong công tác bảo tồn và phát triển cây dược liệu nói chung, đặc biệt là với cây quí hiếm và có giá trị kinh tế cao. Những cây sử dụng bộ phận vỏ thân làm thuốc với 28 loài, chiếm $7,19 \%$ so với tổng số loài. Sử dụng củ 22 loài, chiếm $5,66 \%$ và sử dụng hạt với 21 loài, chiếm $5,39 \%$. Tuy nhiên các bộ phận này có tỷ lệ sử dụng càng lớn thì mức độ ảnh hưởng của việc khai thác càng cao đến khả năng tái sinh của cây. Các bộ phận sử dụng còn lại như vỏ rễ, quả, hoa, nhựa được sử dụng với tần số thấp nhưng tác dụng chữa bệnh rất hiệu quả. Phân bố không đồng đều trong các bộ phận sử dụng làm thuốc là do đặc tính về thời vụ và tích lũy kinh nghiệm chữa bệnh của dân tộc Khơ Mú.

\section{3. Đa dạng về giá trị sử dụng chũa bệnh của các loài cây thuốc}

Kết quả điều tra về đa dạng công dụng chữa bệnh của các loài cây thuốc trong cộng đồng dân tộc Khơ Mú ở khu vực nghiên cứu có những nét độc đáo và mang tính gia truyền được ghi nhận tại Bảng 4 . Các nhóm bệnh chữa trị được kết hợp từ rất nhiều loài cây thuốc khác nhau. Trong một bài thuốc chữa 
những bệnh đơn giản thì chỉ cần đơn loài hoặc vài loài thuốc là đủ, nhưng những bệnh khó chữa thì cần phối rất nhiều loài cây thuốc khác nhau với tỷ lệ khác nhau, tùy từng loại bệnh. Kết quả Bảng 4 cho thấy, cộng đồng dân tộc Khơ Mú ở khu vực nghiên cứu sử dụng kiến thức và kinh nghiệm để chữa trị được 18 nhóm bệnh khác nhau. Trong đó số lượng các loài cây thuốc chữa nhóm bệnh tiêu hóa có số lượng nhiều nhất với 104 loài, chiếm 26,22 \% thuộc 49 họ và 79 chi, bệnh về đường tiêu hóa bao gồm nhiều bệnh khác nhau như nhiễm khuẩn đường ruột, táo bón, dạ dày, viêm gan,... là nhóm bệnh thường gặp trong các loại bệnh mắc phải ở mọi người dân Việt Nam. Xuất phát từ thực tế đó nên nhóm bệnh này có nhiều cách chữa trị khác nhau dựa trên vốn hiểu biết khác nhau của dân tộc Khơ Mú. Điều này cũng gặp tương tự đối với nhóm bệnh về bệnh ngoài da và xương khớp đây là những nhóm bệnh rất thường gặp có thể do từ tập quán làm nông nghiệp, nương rẫy, điều kiện sinh hoạt kém phát triển cũng như đặc điểm khí hậu nhiệt đới, nóng ẩm của Việt Nam; đặc biệt là người dân thường xuyên vào rừng khai thác tài nguyên nên dễ gặp tai nạn, ảnh hưởng tới xương, cơ bắp cụ thể nhóm bệnh ngoài da chiếm tỷ lệ 23,91\%, gồm 93 loài trong tổng số 389 loài thu được, thuộc 51 họ và 89 chi và nhóm bệnh về xương khớp, gân, cơ chiếm 18,77\%, gồm 73 loài so với tổng số loài thu được, thuộc 43 họ và 62 chi. Kết quả tương tự cũng được chỉ ra trong nghiên cứu kinh nghiệm về bài thuốc chữa bệnh của các các dân tộc thiểu số ở tỉnh Thái Nguyên của Lê Thị Thanh Hương, Nguyễn Trung Thành [5]. Nhóm bệnh phụ nữ với 54 loài, chiếm $13,88 \%$ so với tổng số loài thu được, thuộc 40 họ và 54 chi. Nhóm bệnh bài tiết với 40 loài, chiếm $10,28 \%$ so với tổng số loài thu được, thuộc 33 họ và 40 chi. Nhóm bệnh hô hấp với 40 loài, chiếm $10,28 \%$ so với tổng số loài thu được, thuộc 34 họ và 40 chi. Có 38 loài có tiềm năng chữa bệnh động vật cắn, chiếm $9,77 \%$, thuộc 25 họ và 38 chi. Có 33 loài có tiềm năng chữa bệnh tim mạch chiếm $8,48 \%$ thuộc 26 họ và 28 chi. Có 32 loài có tiềm năng chữa bệnh thần kinh chiếm $8,23 \%$ thuộc 24 họ và 32 chi. Có 14 loài có tiềm năng bồi bổ cơ thể chiếm 3,59\%, thuộc 14 họ và 41 chi. Các nhóm bệnh còn lại có số loài có tiềm năng chữa bệnh dưới 14 loài.

Trong số 389 cây thuốc thu thập được, có cây chỉ được ghi nhận để chữa trị một bệnh nhưng cũng có một số cây được dùng để chữa trị hai hay nhiều loại bệnh khác nhau. Cùng một cây thuốc nhưng với mỗi người dân tộc Khơ Mú lại có kinh nghiệm, phương thức điều trị được nhiều bệnh khác nhau cho thấy nguồn tài nguyên tri thức tại đây rất phong phú, phương thức chữa trị bệnh độc đáo. Mỗi phương thức lại chỉ tồn tại trong một vài người, vài gia đình hay trong một cộng đồng nhỏ,... đây là nguồn tri thức quý giá nhưng có nguy cơ thất truyền cao khi những người này qua đời do vậy cần được phải biện pháp thu thập lưu giữ.

Mỗi loại cây thuốc sẽ có những cách chế biến khác nhau tùy thuộc vào cách chữa của từng ông lang, bà mế và tùy thuộc vào tình trạng của người bệnh. Trong đó, phương pháp dùng tươi là nhiều nhất, sở dĩ như vậy là do dân tộc Khơ Mú ở đây sinh sống ngay tại khu vực có rừng, nguồn tài nguyên có sẵn nên khi nào có nhu cầu sử dụng họ mới đi lấy về. Một lý do khác là theo quan niệm của người dân, các cây thuốc khi dùng tươi thì hiệu quả cao hơn so với dùng khô, vì phơi khô nếu không bảo quản tốt sẽ bị mốc khi dùng gây hại cho sức khỏe, tiếp đó là thái lát mỏng phơi khô đun nước uống cũng được sử dụng nhiều hiện nay, bởi vì nhiều cây thuốc phải đi vào rừng sâu mới có, ngoài ra có thể đun nước tắm, xông hơi, ngâm rượu để uống hoặc xoa bóp,... khi đi lấy thuốc lấy vào lúc sáng sớm. 
Nhìn chung từ kết quả ở trên đã chỉ ra rằng kinh nghiệm sử dụng cây thuốc cũng như cách chữa trị bệnh từ nguồn cây thuốc của cộng đồng dân tộc Khơ Mú rất đa dạng và độc đáo.

Bảng 4. Tỷ lệ số loài cây thuốc có công dụng chữa bệnh

\begin{tabular}{|c|l|c|c|}
\hline Stt & \multicolumn{1}{|c|}{ Các nhóm bệnh } & $\begin{array}{c}\text { Số } \\
\text { lượng } \\
\text { loài }\end{array}$ & $\begin{array}{c}\text { Tỷ lệ } \\
\text { (\%) }\end{array}$ \\
\hline 1 & Tiêu hoá (Tiêu chảy, lỵ, viêm gan, xơ gan, đau dạ dày, ruột...) & 102 & 26,22 \\
\hline 2 & Ngoài da (Dị ứng, nhọt, nước ăn chân...) & 93 & 23,91 \\
\hline 3 & $\begin{array}{l}\text { Xương khớp, gân (Gẫy xương, đau lưng, đau khớp gối, mỏi cơ, tê thấp, } \\
\text { đứt gân...) }\end{array}$ & 73 & 18,77 \\
\hline 4 & $\begin{array}{l}\text { Bệnh phụ nữ (An thai, hiếm muộn, tắc tia sữa, kinh nguyệt không đều, } \\
\text { băng huyết....) }\end{array}$ & 54 & 13,88 \\
\hline 5 & Bài tiết (Đường tiết niệu, lợi tiểu, sỏi thận, đái rắt, đái buốt....) & 40 & 10,28 \\
\hline 6 & Hô hấp (Viêm họng, ho, hen, viêm xoang...) & 40 & 10,28 \\
\hline 7 & Động vật cắn (Rắn cắn, ong cắn, rết cắn...) & 38 & 9,77 \\
\hline 8 & Tim mạch (Cầm máu, huyết áp cao, tụ máu đông, tai biến mạch máu não...) & 33 & 8,48 \\
\hline 9 & Thần kinh (Đau đầu, an thần, thần kinh tọa ...) & 32 & 8,23 \\
\hline 10 & Bồi bổ cơ thể (Bổ máu, bổ thân, bố gan, ....) & 14 & 3,59 \\
\hline 11 & Giải độc (Ngộ độc rượu, nấm, ngộ độc thức ăn...) & 13 & 3,34 \\
\hline 12 & Bệnh nam giới (Xuất tinh sớm, yếu sinh lý, viêm tinh hoàn...) & 10 & 2,57 \\
\hline 13 & Bệnh trẻ em (Nhanh biết đi, .....) & 8 & 2,06 \\
\hline 14 & Đái tháo đường & 4 & 1,03 \\
\hline 15 & U bướu (Ung thư, hạch, u nang ...) & 3 & 0,77 \\
\hline 16 & Bệnh về mắt (Đau mắt...) & 2 & 0,51 \\
\hline 17 & Bệnh về tai (Ve chiu vào tai, viêm tai) & 2 & 0,51 \\
\hline 18 & Thuốc cho động vật nuôi (Đau bụng của trâu bò, phòng dịch toi gà...) & 2 & 0,51 \\
\hline
\end{tabular}

Kết quả điều tra về đa dạng công dụng chữa bệnh của các loài cây thuốc trong cộng đồng dân tộc Khơ Mú ở khu vực nghiên cứu có những nét độc đáo và mang tính gia truyền được ghi nhận tại Bảng 4. Các nhóm bệnh chữa trị được kết hợp từ rất nhiều loài cây thuốc khác nhau. Trong một bài thuốc chữa những bệnh đơn giản thì chỉ cần đơn loài hoặc vài loài thuốc là đủ, nhưng những bệnh khó chữa thì cần phối rất nhiều loài cây thuốc khác nhau với tỷ lệ khác nhau, tùy từng loại bệnh. Kết quả Bảng 4 cho thấy, cộng đồng dân tộc Khơ Mú ở khu vực nghiên cứu sử dụng kiến thức và kinh nghiệm để chữa trị được 18 nhóm bệnh khác nhau. Trong đó số lượng các loài cây thuốc chữa nhóm bệnh tiêu hóa có số lượng nhiều nhất với 104 loài, chiếm $26,22 \%$ thuộc 49 họ và 79 chi, bệnh về đường tiêu hóa bao gồm nhiều bệnh khác nhau như nhiễm khuẩn 
đường ruột, táo bón, dạ dày, viêm gan..., là nhóm bệnh thường gặp trong các loại bệnh mắc phải ở mọi người dân Việt Nam. Xuất phát từ thực tế đó nên nhóm bệnh này có nhiều cách chữa trị khác nhau dựa trên vốn hiểu biết khác nhau của dân tộc Khơ Mú. Điều này cũng gặp tương tự đối với nhóm bệnh về bệnh ngoài da và xương khớp đây là những nhóm bệnh rất thường gặp có thể do từ tập quán làm nông nghiệp, nương rẫy, điều kiện sinh hoạt kém phát triển cũng như đặc điểm khí hậu nhiệt đới, nóng ẩm của Việt Nam; đặc biệt là người dân thường xuyên vào rừng khai thác tài nguyên nên dễ gặp tai nạn, ảnh hưởng tới xương, cơ bắp cụ thể nhóm bệnh ngoài da chiếm tỷ lệ $23,91 \%$, gồm 93 loài trong tổng số 389 loài thu được, thuộc 51 họ và 89 chi và nhóm bệnh về xương khớp, gân, cơ chiếm $18,77 \%$, gồm 73 loài so với tổng số loài thu được, thuộc 43 họ và 62 chi. Kết quả tương tự cũng được chỉ ra trong nghiên cứu kinh nghiệm về bài thuốc chữa bệnh của các các dân tộc thiểu số ở tỉnh Thái Nguyên của Lê Thị Thanh Hương, Nguyễn Trung Thành [5]. Nhóm bệnh phụ nữ với 54 loài, chiếm 13,88\% so với tổng số loài thu được, thuộc 40 họ và 54 chi. Nhóm bệnh bài tiết với 40 loài, chiếm 10,28\% so với tổng số loài thu được, thuộc 33 họ và 40 chi. Nhóm bệnh hô hấp với 40 loài, chiếm 10,28\% so với tổng số loài thu được, thuộc 34 họ và 40 chi. Có 38 loài có tiềm năng chữa bệnh động vật cắn, chiếm $9,77 \%$, thuộc 25 họ và 38 chi. Có 33 loài có tiềm năng chữa bệnh tim mạch chiếm $8,48 \%$ thuộc 26 họ và 28 chi. Có 32 loài có tiềm năng chữa bệnh thần kinh chiếm $8,23 \%$ thuộc 24 họ và 32 chi. Có 14 loài có tiềm năng bồi bổ cơ thể chiếm 3,59\%, thuộc 14 họ và 41 chi. Các nhóm bệnh còn lại có số loài có tiềm năng chữa bệnh dưới 14 loài. Trong số 389 cây thuốc thu thập được, có cây chỉ được ghi nhận để chữa trị một bệnh nhưng cũng có một số cây được dùng để chữa trị hai hay nhiều loại bệnh khác nhau. Cùng một cây thuốc nhưng với mỗi người dân tộc Khơ Mú lại có kinh nghiệm, phương thức điều trị được nhiều bệnh khác nhau cho thấy nguồn tài nguyên tri thức tại đây rất phong phú, phương thức chữa trị bệnh độc đáo. Mỗi phương thức lại chỉ tồn tại trong một vài người, vài gia đình hay trong một cộng đồng nhỏ,... đây là nguồn tri thức quý giá nhưng có nguy cơ thất truyền cao khi những người này qua đời do vậy cần được phải biện pháp thu thập lưu giữ. Mỗi loại cây thuốc sẽ có những cách chế biến khác nhau tùy thuộc vào cách chữa của từng ông lang, bà mế và tùy thuộc vào tình trạng của người bệnh. Trong đó, phương pháp dùng tươi là nhiều nhất, sở dĩ như vậy là do dân tộc Khơ Mú ở đây sinh sống ngay tại khu vực có rừng, nguồn tài nguyên có sẵn nên khi nào có nhu cầu sử dụng họ mới đi lấy về. Một lý do khác là theo quan niệm của người dân, các cây thuốc khi dùng tươi thì hiệu quả cao hơn so với dùng khô, vì phơi khô nếu không bảo quản tốt sẽ bị mốc khi dùng gây hại cho sức khỏe, tiếp đó là thái lát mỏng phơi khô đun nước uống cũng được sử dụng nhiều hiện nay,bởi vì nhiều cây thuốc phải đi vào rừng sâu mới có, ngoài ra có thể đun nước tắm, xông hơi, ngâm rượu để uống hoặc xoa bóp,... khi đi lấy thuốc lấy vào lúc sáng sớm. Nhìn chung từ kết quả ở trên đã chỉ ra rằng kinh nghiệm sử dụng cây thuốc cũng như cách chữa trị bệnh từ nguồn cây thuốc của cộng đồng dân tộc Khơ Mú rất đa dạng và độc đáo.

\section{4. Đa dạng về môi truờng sống của nguồn tài nguyên cây thuốc}

Kết quả điều tra nghiên cứu đã xác định được môi trường sống của cây thuốc là rất đa dạng với 7 kiểu chính. Các dạng môi trường sống đã được xác định ghi tại Bảng 5

Qua dẫn liệu trên cho thấy môi trường của các loài cây thuốc ở khu vực nghiên cứu rất đa dạng 
và phong phú, trong đó cây thuốc phân bố ở môi trường rừng là chiếm tỷ lệ cao nhất đạt $95,11 \%$ (với 370 loài), đứng thứ hai là môi trường sống ở nương rẫy, nương rẫy bỏ hoang, thảm cỏ chiếm tỷ lệ 52,44\% (với 204 loài).Tiếp theo ven đường chiếm tỷ lệ 26,74\% (với 104 loài) đây đều là những cây ưa sáng như cây Thôi ba (Alangium chinense (Lour.)) dùng trị rắn cắn; cây Muối (Rhus chinensis Mill.) chữa thận, dị ứng, Bùm bụp (Mallotus barbatus Muell.-Arg) chữa gãy xương ...; trong vườn nhà chiếm tỷ lệ 25,96\% (với 101 loài). Việc đem cây thuốc về trồng tại vườn là một việc làm cần thiết, vừa có thể sử dụng ngay khi cần lại vừa có tác dụng bảo tồn và duy trì nguồn gen cây thuốc. Theo ông các ông lang, bà mế thì trước kia vào rừng gặp nhiều cây thuốc quý, nhưng giờ những cây thuốc quý rất hiếm phải vào trong rừng sâu mới có, những cây như: Lan kim tuyến (Anoectocchilus setaceus Blume), $\mathrm{Na}$ rừng (Kadsura heteroclita (Roxb.) Craib)... Thảm cây bụi chiếm tỷ lệ $20,57 \%$ (với 80 loài); Quanh bản chiếm tỷ lệ 9,51\% (với 37 loài) và thấp nhất khe nước, suối, ao, ruộng ẩm, nơi ẩm ướt chiếm tỷ lệ 9,25\% (với 36 loài) đại diện như Hồi nước (Limnophila rugosa (Roth) Merr), Thiên niên kiện (Homalomena gigantea Engl.)... Điều này cho thấy sự đa dạng và phong phú trong vấn đề sử dụng thuốc của dân tộc Khơ Mú nơi đây, các cây thuốc được sử dụng có khu vực phân bố rộng, tuy nhiên ý thức nhân rộng mô hình bảo tồn cây thuốc ở môi trường vườn vẫn chưa cao.

Bảng 5. Sự phân bố nguồn cây thuốc theo môi trường sống ở khu vực nghiên cứu.

\begin{tabular}{|c|c|c|c|c|}
\hline STT & Môi trường sống & Kí hiệu & Số loài & $\begin{array}{c}\text { Tỉ lệ } \\
(\mathbf{\%})\end{array}$ \\
\hline 1 & Sổng ở rừng( Rừng nguyên sinh, rừng thứ sinh, ven rừng) & $\mathrm{R}$ & 370 & 95,11 \\
\hline 2 & Nương rẫy, nương rẫy bỏ hoang, thảm cỏ & $\mathrm{NR}$ & 204 & 52,44 \\
\hline 3 & Ven đường & VĐ & 104 & 26,74 \\
\hline 4 & Vườn nhà & $\mathrm{VN}$ & 101 & 25,96 \\
\hline 5 & Thảm cây bụi & TCB & 80 & 20,57 \\
\hline 6 & Quanh bản & Qb & 37 & 9,51 \\
\hline 7 & Khe nước, suối, ao, ruộng ẩm, nơi ẩm ướt & Kh & 36 & 9,25 \\
\hline
\end{tabular}

\section{Ghi chú: * Có nhũng loài phân bố cả 2 - 3 môi truò̀ng}

3.5. Một số loài cây thuốc bị đe dọa cần được bảo vệ

Tại khu vực nghiên cứu thực vật được khai thác để chữa bệnh cho người dân địa phương với lượng không nhiều, nhưng khai thác vì mục đích thương mại theo đường tiểu ngạch với số lượng rất lớn, đây là nguyên nhân chính làm cho số loài thực vật có nguy cơ tuyệt chủng tăng cao đã dẫn đến nhiều loài cây thuốc bị suy giảm nghiêm trọng và có nguy cơ bị tuyệt chủng ngoài thiên nhiên, được ghi nhận trong Sách Đỏ (2007) [20] và Danh lục Đỏ cây thuốc Việt Nam [21] và Nghị định 06/2019/NĐ-CP [22]. Bước đầu đã thống kê được một số loài cây thuốc quý hiếm, có nguy cơ cạn kiệt hoặc đang bị đe dọa tuyệt chủng (Bảng 6). Kết quả điều tra đã ghi nhận được 28 loài cây thuốc quý hiếm. Trong đó, có 15 loài cây thuốc ở mức độ sẽ nguy cấp, xếp ở thứ hạng VU (sắp nguy cấp), 12 loài đang ở mức nguy cấp cần được bảo vệ (EN nguy cấp) và 1 loài ở thứ hạng CR(cực kỳ nguy cấp) trong Sách đỏ Việt Nam (2007) [20]. Theo Danh lục đỏ cây thuốc Việt Nam của Nguyễn Tập [21] có 18 loài trong đó có 4 loài cây thuốc ở thứ hạng VU (sắp nguy cấp), 13 loài ở thứ hạng EN (nguy cấp) và 1 loài ở thứ hạng CR (cực kỳ nguy cấp), có 12 loài thuộc 
Nghị định 06/2019/NĐ-CP [7], trong đó có 1 loài thuộc nhóm IA và 11 loài thuộc nhóm IIA. Đây là những loài cây thuốc quí đang bị khai thác mạnh cần quan tâm và có chính sách ưu tiên trong việc bảo tồn và phát triển.

Bảng 6. Các loài thực vật qúy hiếm cần được bảo tồn tại khu vực nghiên cứu.

\begin{tabular}{|c|c|c|c|c|c|}
\hline \multirow[b]{2}{*}{ Stt } & \multirow[b]{2}{*}{ Tên khoa học } & \multirow[b]{2}{*}{$\begin{array}{l}\text { Tên phổ } \\
\text { thông }\end{array}$} & \multicolumn{3}{|c|}{ Cấp quy định } \\
\hline & & & $\begin{array}{c}\text { Sách } \\
\text { Đỏ Việt } \\
\text { Nam } \\
2007\end{array}$ & $\begin{array}{c}\text { Danh lục } \\
\text { Đỏ cây } \\
\text { thuốc } \\
\text { Việt Nam } \\
2019\end{array}$ & $\begin{array}{l}\text { 06/2019/ } \\
\text { NĐ-CP }\end{array}$ \\
\hline 1 & Acanthopanax trifoliatus (L.) Voss & Ngũ gia bì gai & EN & VU & \\
\hline 2 & $\begin{array}{l}\text { Acorus macrospadiceus (Yam.)F } \\
\text {.N.Wei \& Y.K.Li. }\end{array}$ & $\begin{array}{l}\text { Thủy xương } \\
\text { bồ lá to }\end{array}$ & EN & EN & \\
\hline 3 & Anoectocchilus setaceus Blume. & Lan kim tuyến & EN & EN & IA \\
\hline 4 & Balanophora laxiflora Hemsl. & Dó đất & EN & $\mathrm{EN}$ & \\
\hline 5 & Canarium tramdenanum Dai \& Yakovl. & Trám đen & VU & & \\
\hline 6 & $\begin{array}{l}\text { Cinnamomum partheroxylon (Jack.) } \\
\text { Meisn. }\end{array}$ & Re hương & $\mathrm{CR}$ & & IIA \\
\hline 7 & Cirsium japonicum Fish.ex DC. & Đại kế & VU & & \\
\hline 8 & Codonopsis javanica (Blume) Hook.f. & Đảng sâm & VU & EN & IIA \\
\hline 9 & Curculigo orchioides Gaertn & Sâm cau & EN & EN & \\
\hline 10 & Dendrobium aphyllum (Roxb.) C. Fisch. & Hạc vĩ & VU & & IIA \\
\hline 11 & Dendrobium chrysanthum Lindl. & Ngọc vạn vàng & EN & & IIA \\
\hline 12 & Disporopsis longifolia Craib & $\begin{array}{l}\text { Hoàng tinh } \\
\text { cách }\end{array}$ & VU & $\mathrm{EN}$ & IIA \\
\hline 13 & Drynaria bonii C. Chr. & Tắc kè đá & VU & VU & IIA \\
\hline 14 & $\begin{array}{l}\text { Drynaria fortunei (Kuntz. ex Mettt.) J. } \\
\text { Smith }\end{array}$ & Cốt toái bổ & $\mathrm{EN}$ & $\mathrm{EN}$ & IIA \\
\hline 15 & Elsholtzia penduliflora W. W.Smith & Chùa dù & VU & EN & \\
\hline 16 & $\begin{array}{l}\text { Fallopia multiflora (Thumb.) } \\
\text { Haraldson }\end{array}$ & Hà thủ ô đỏ & VU & $\mathrm{EN}$ & \\
\hline 17 & $\begin{array}{l}\text { Gynostmma pentaphyllum (Thunb.) } \\
\text { Makino }\end{array}$ & Giảo cổ lam & $\mathrm{EN}$ & & \\
\hline 18 & Homalomena gigantea Engl. & Thiên niên kiện & VU & & \\
\hline 19 & Kadsura heteroclita (Roxb.) Craib & $\mathrm{Na}$ rừng & VU & EN & IIA \\
\hline 20 & Limnophila rugosa (Roth) Merr & Hồi nước & VU & & \\
\hline 21 & Melientha suavis Pierre & Rau sắng & VU & & \\
\hline 22 & $\begin{array}{l}\text { Murraya glabrum (Guillaum.) } \\
\text { Guillaum. }\end{array}$ & Vương tùng & VU & & \\
\hline
\end{tabular}




\begin{tabular}{|c|l|c|c|c|c|}
\hline 23 & Nervilia fordii (Hance) Schlechter & Lan một lá & EN & EN & IIA \\
\hline 24 & Paris polyphylla Smith & Bảy lá 1 hoa & EN & CR & IIA \\
\hline 25 & Polygonatum kingianum Coll ex Hemsl. & $\begin{array}{c}\text { Hoàng tinh } \\
\text { vòng }\end{array}$ & EN & EN & IIA \\
\hline 26 & $\begin{array}{l}\text { Selaginella tamariscima } \text { (Beauv.) } \\
\text { Spring }\end{array}$ & $\begin{array}{c}\text { Quyển bá } \\
\text { trường sinh }\end{array}$ & VU & VU & \\
\hline 27 & Stephania brachyandra Diels & $\begin{array}{c}\text { Bình vồi nhị } \\
\text { ngắn }\end{array}$ & EN & EN & \\
\hline 28 & Stemona cochinchinensis Gagnep & Bách bộ & VU & VU & \\
\hline
\end{tabular}

* Ghi chú: EN (Nguy cấp); VU (Sắp nguy cấp); CR (Cực kỳ nguy cấp)

\section{Kết luận}

Kết quả điều tra các loài cây thuốc được dân tộc Khơ Mú sử dụng ở rừng Đặc dụng, Phòng hộ Sốp Cộp, tỉnh Sơn La đã ghi nhận được 389 loài cây thuốc thuộc 109 họ, 294 chi. Ngành Ngọc lan đa dạng nhất, chiếm $94,09 \%$ tổng số loài, $93,88 \%$ tổng số chi và $86,25 \%$ tổng số họ. Tỷ trọng của lớp Hai lá mầm so với lớp Một lá mầm trong ngành Ngọc Lan luôn cao hơn 3 , có khi đạt đến 4,2. Điều này cho thấy hệ thực vật nơi đây mang tính chất nhiệt đới. Đa dạng ở bậc dưới ngành: 10 họ có số loài đa dạng nhất, chiếm $3,4 \%$ tổng số họ. Chi Sung (Ficus) và Rau răm (Polygonum) có số loài nhiều nhất với 7 loài. Nơi phân bố cây thuốc ở các dạng sinh cảnh như: ở rừng, nương rẫy, ven đường, vườn nhà, thảm cây bụi, khe nước ẩm.Trong các bộ phận được sử dụng làm thuốc lá được sử dụng nhiều nhất với 104 loài, sau đó là thân với 88 loài. Bộ phận cả cây, rễ cũng được sử dụng khá lớn cụ thể cả cây với 77 loài, rễ với 66 loài. Đã thống kê được 18 nhóm bệnh khác nhau được sử dụng để chữa bệnh. Số lượng cây thuốc thuộc diện cần bảo tồn ở khu vực nghiên cứu có 28 loài, chiếm 7,19\% tổng số loài cây thuốc thu được.

\section{Lò̀i cảm ơn}

Nhóm tác giả xin chân thành cảm ơn sự tài trợ kinh phí từ đề tài cấp Bộ (Bộ Giáo dục và
Đào tạo),mã số CT-2019.06.05 thuộc Chương trình CT.2019.06. Xin bày tỏ lòng biết ơn tới Ban quản lý, cán bộ rừng Đặc dụng, phòng hộ Sốp Cộp tỉnh Sơn La đã tạo điều kiện thuận lợi trong quá trình nghiên cứu. Cảm ơn các thầy thuốc cổ truyền dân tộc Khơ Mú, người thu hái cây thuốc và người dân địa phương xã Sốp Cộp, Dổm Cang và Huổi Một đã tham gia phỏng vấn, khảo sát thực địa.

\section{Tài liệu tham khảo}

[1] Son La Agriculture and Forestry Planning and Design Center, Report on conservation and sustainable development planning for Sop Cop special-use forest up to 2020.95 pages, 2013.

[2] P. Q . Anh, T. T. Bach, V. T. Lien. Diversity of Medicinal Plants of Magnoliophyta in Ta Xua Nature Reserve Area, Son La province, VNU Journal of Science: Natural Science and Technology, Vol. 32, 2016, pp. 8-13. (in Vietnamese)

[3] V. T. Lien, N. T. Tuyen, L. T. T.Hieu. Diversity of Medicinal Plants Species in Long He Commune, Thuan Chau District, Son La Province. Journal of Agriculture and Rural Development, 2016, 204- 209.

[4] V. T. Lien, H. T. Me, H. T. T. Ha. The Survey of Medicinal Plants and Their Use by the Mong Ethnic Minority at Muong Phang Commune, Dien Bien District, Dien Bien Province. The 7th National Scientific Conference on Ecology and Biological Resources, 2017, pp. 1311-1316

[5] L. T. L. Huong, N. T. Thanh. The Knowledge and Experience of the Medicinal Plants Using of Minorities Ethnic in Thai Nguyen Province for Conservation and Sustainable Development. VNU Journal of Science: Natural Science and Technology, Vol. 32(1), 2016, pp. 55-64. (in Vietnamese) 
[6] A. Asase, A. A. Oteng-Yeboah, G. T. Odamtten and M. S. Simmonds, Ethnobotanical Study of Some Ghanaian Anti-Malarial Plants, Journal of Ethnopharmacology, Vol. 99(2), 2005, pp. 273-279.

[7] M. Ayyanar, S. Ignacimuthu, Traditional Knowledge of Kani Tribals in Kouthalai of Tirunelveli hills, Tamil Nadu, India, Journal of Ethnopharmacol, Vol. 102(2), 2005, pp. 246-55

[8] C. Muthu, M. Ayyanar, N. Raja, S. Ignacimuthu, Medicinal Plants Used by Traditional Healers in Kancheepuram District of Tamil Nadu, India, J. Ethnobiol Ethnomed, Vol. 2, 2006, pp. 43.

[9] Yineger H. and D. Yewhalaw, Traditional Medicinal Plant Knowledge and Use by Local Healers in Sekoru District, Jimma Zone, Southwestern Ethiopia, Journal of Ethnobiology and Ethnomedicine, Vol. 3, 2007, pp. 24.

[10] T. T. T. Huyen, Research on Medicinal Plant Diversity in Sop Cop Nature Reserve, Son La Province. Master's thesis in Biology, Hanoi, 2013. (in Vietnamese) [11] V. T. Lien, N. T. Quyen, D. H. Thu. Diversity of Essential Oils in Sop Cop Nature Reserve in Sơn La province.VNU Journal of Science: Natural Sciences and Technology, Vol. 35(3), 2019, pp. 39-46 (in Vietnamese)

[12] N. T. Nguyen, Methods of Plant Research. Hanoi National University Publisher, 2007. (in Vietnamese)

[13] P. H. Ho, An Illustrated Flora of Vietnam. Youth Publisher, 1999 (in Vietnamese).

[14] N. T. Ban, List of Vietnamese Plant Species. Agriculture Publishing House, Hanoi, 2003 (in Vietnamese).
[15] V. V. Chi, Vietnamese Medicinal Plants Dictionary. Hanoi Medical Publishing House, 2012 (in Vietnamese).

[16] D. T. Loi, Vietnamese Medicinal Plants and Herbs. Science and Technology Publishing House, Hanoi, 2005 (in Vietnamese).

[17] T. D. Ly, 1900 useful species. World Publishing House, Hanoi, 1995 (in Vietnamese).

[18] R. K. Brummitt, Vascular Plant Families and General, Royal Botanic Gardens, Kew, 1992 Vascular Plant Families and Genera, Royal Botanic Gardens, Kew, 1992.

[19] G. J. Martin, Ethnology. Conservation book. Agriculture Publishing House, 2002 (in Vietnamese).

[20] Ministry of Science and Technology, Vietnam Academy of Science and Technology,Vietnam Red Book (Part II - Plant). Science and Technology Publishing House, Hanoi, 2007 (in Vietnamese).

[21] N. Tap, Red List of Vietnamese Medicinal Plants, Journal of Medicinal Materials, Vol. 6, 2019, pp. 319328

[22] Government of the Socialist Republic of Vietnam, Decree 06/2019 / CP-ND, dated 22 January 2019 on the Management of Endangered, Precious and Rare Forest Plants and Animals and the Implementation of the Convention on International Trade in Endangered Wild Fauna and Flora Species (in Vietnamese).

[23] P. B. Quyen, N. N. Thin. Biodiversity. VNU Publishing House, Hanoi, 2002 (in Vietnamese). 